"This is the peer reviewed version of the following article: [Chem. Eur. J . $2015,21, \quad 1 \quad 0754-10762$

], which has been published in

final form at [http://onlinelibrary.wiley.com/doi/10.1002/chem.201501576/abstract]. This article may be used for noncommercial purposes

in accordance with Wiley Terms and Conditions for Self-Archiving ."

\title{
Highly Chemo-Selective Catalytic Coupling of Substituted Oxetanes and Carbon Dioxide
}

Jeroen Rintjema, ${ }^{[a]}$ Wusheng Guo, ${ }^{[a]}$ Eddy Martin, ${ }^{[a]}$ Eduardo C. Escudero-Adán, ${ }^{[a]}$ Arjan W. Kleij ${ }^{\text {[a][b] }}$

\begin{abstract}
The chemo-selective coupling of oxetanes and carbon dioxide to afford functional, heterocyclic organic compounds known as six-membered cyclic carbonates remains a challenging topic. Here we describe an effective method for their synthesis relying on the use of Al-catalysis. The catalytic reactions can be carried out with excellent selectivity for the cyclic carbonate product tolerating various (functional) groups present in the 2- and 3-position(s) of the oxetane ring, and the presented methodology is the first general approach towards the formation of six-membered cyclic carbonates (6MCCs) through oxetane $/ \mathrm{CO}_{2}$ coupling chemistry. Apart from a series of substituted six-membered cyclic carbonates, also the unprecedented room temperature coupling of oxetanes and $\mathrm{CO}_{2}$ is disclosed giving, depending on the structural features of the substrate, a variety of five- and six-membered heterocyclic products. $A$ mechanistic rationale is presented for their formation and support for the intermediary presence of a carbonic acid derivative is given. The presented functional carbonates may hold great promise as building blocks in organic synthesis and the
\end{abstract}

[a] J. Rintjema, Dr. W. Guo, Dr. E. Martin, E.C. Escudero-Adán, Prof. Dr. A. W. Kleij

Institute of Chemical Research of Catalonia (ICIQ), Av. Països Catalans 16, 43007 Tarragona, Spain

E-mail: akleij@iciq.es

[b] Prof. Dr. A. W. Kleij

Catalan Institute of Research and Advanced Studies (ICREA), Pg.

Lluís Companys 23, 08010 Barcelona, Spain

Supporting information for this article is given via a link at the end of the document. development of new, biodegradable polymers.

\section{Introduction}

The use of carbon dioxide $\left(\mathrm{CO}_{2}\right)$ as a renewable carbon feed stock for the preparation of value added organic intermediates, building blocks and polymers has grown tremendously over the years. ${ }^{[1]}$

Amplification of the portfolio of useful compounds derived from $\mathrm{CO}_{2}$ may allow for an alternative route towards important chemicals that are still largely based on fossil fuel feed stocks. ${ }^{[2]}$ Therefore it remains important to develop new and efficient catalytic strategies that help to widen the scope of products that incorporate $\mathrm{CO}_{2}$ as a molecular synthon. ${ }^{[3]} \mathrm{An}$ area of profound interest is the formation of organic carbonates with both $\mathrm{cyclic}^{[4]}$ as well as polymeric carbonates ${ }^{[5]}$ having increasing academic focus and industrial potential. ${ }^{[1 a, 6]}$ The field of cyclic carbonates has been dominated by the formation of fivemembered structures using either organo-catalytic ${ }^{[7]}$ or metal-based catalysts. ${ }^{[8]}$ The most commonly used synthetic approach is the coupling between oxiranes (epoxides) and $\mathrm{CO}_{2}$ in the presence of a suitable Lewis acidic metal catalyst and an external nucleophile (i.e., a binary catalyst system). The coupling reaction between oxetanes and $\mathrm{CO}_{2}$ to give six-membered carbonates has been largely neglected; activation of oxetanes and their coupling reaction with $\mathrm{CO}_{2}$ is generally considered a huge challenge with only a few known catalytic systems able to promote this oxetane conversion. ${ }^{[9]}$ 
The group of Darensbourg has extensively studied the metal catalyzed formation of polycarbonates derived from oxetane ${ }^{[10]}$ and a limited number of 3,3'disubstituted oxetanes; ${ }^{[11]}$ their work demonstrated that poly(carbonate) formation may (partially) result from ring-opening polymerization (ROP) of a preformed six-membered cyclic carbonate (6MCC), a process being more pronounced when using more substituted oxetanes giving the thermodynamically favored polycarbonates as end-products. Therefore, new catalytic methods are still required to favour chemo-selectivity towards the cyclic carbonate product. The ROP of 6MCCs has shown great potential for the preparation of (bio)degradable poly(carbonates) ${ }^{[12]}$ with useful applications in medical devices. ${ }^{[13]}$ The ROP of new types of functional $6 \mathrm{MCC}$ monomers can open up new avenues for polycarbonates with interesting thermal/crystalline properties through post-modification ${ }^{[14]}$ or through a judicious choice of the monomer backbone. However, as far as we know no general method toward the preparation of $6 \mathrm{MCC}$ has been developed limiting thus the use of $\mathrm{CO}_{2}$ /oxetane couplings in synthetic chemistry.

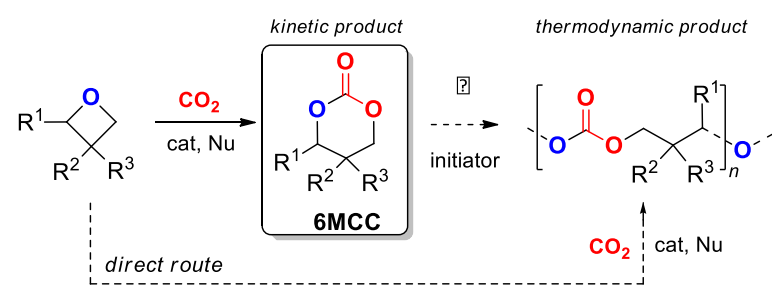

Challenges:

- high chemo-selectivity for $6 M C C$

- mild catalysis conditions ( $p, T)$

- lethargic reactivity of oxetanes

- limited Fg tolerance

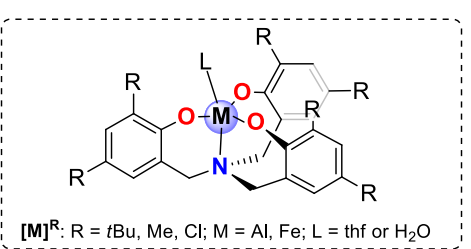

Scheme 1. Formation of 6MCCs and the challenges associated with their formation. Below the catalyst structures used in this work which are based on aminotriphenolate complexes ( $\mathrm{M}=\mathrm{Fe}, \mathrm{Al})$. 
We set out to solve this synthetic challenge and envisioned that the use of $\mathrm{Al}$ (III) and $\mathrm{Fe}$ (III) aminotriphenolate complexes as catalysts for the formation of $6 \mathrm{MCC}$ would provide a good starting point. These complexes have previously been shown to be highly effective catalysts in various coupling reactions of $\mathrm{CO}_{2}$ with highly functionalized oxiranes leading to either poly(carbonate) or multi-cyclic carbonate structures. ${ }^{[15]}$ However, also with these Fe and Al based catalyst systems the selective and high yield formation of a few substituted 6MCCs from oxetane $/ \mathrm{CO}_{2}$ coupling reactions turned out to be problematic and significant amounts of polymer product formed during these investigations (i.e. low chemo-selectivity was observed, cf. Scheme 1). We hypothesized that the peripheral substitution of the aminotriphenolate ligand and the reaction conditions/medium could have a huge impact on the chemo-selective features of the reaction. As the thermodynamically favoured poly(carbonate) product prevails at higher reaction temperatures, we envisioned that for efficient catalysis towards $6 \mathrm{MCC}$ formation relatively mild conditions would be preferred. Also, the catalyst would preferably only actively participate at the initial stage of the reaction, i.e. during the ring-opening of the oxetane substrate mediated by an external nucleophile. Such behaviour is further favoured in the presence of a solvent that has the right polarity features to compete with the metal-alkoxide and/or metal-carbonate bonds present during the intermediate stages of the $6 \mathrm{MCC}$ formation reaction. Here we report on a highly chemo-selective Al-catalyzed coupling reaction between (functional) oxetanes and $\mathrm{CO}_{2}$ leading to their respective $6 \mathrm{MCCs}$ generally in fair to high isolated yields under mild reaction conditions and with an exceptional scope for this type of coupling chemistry.

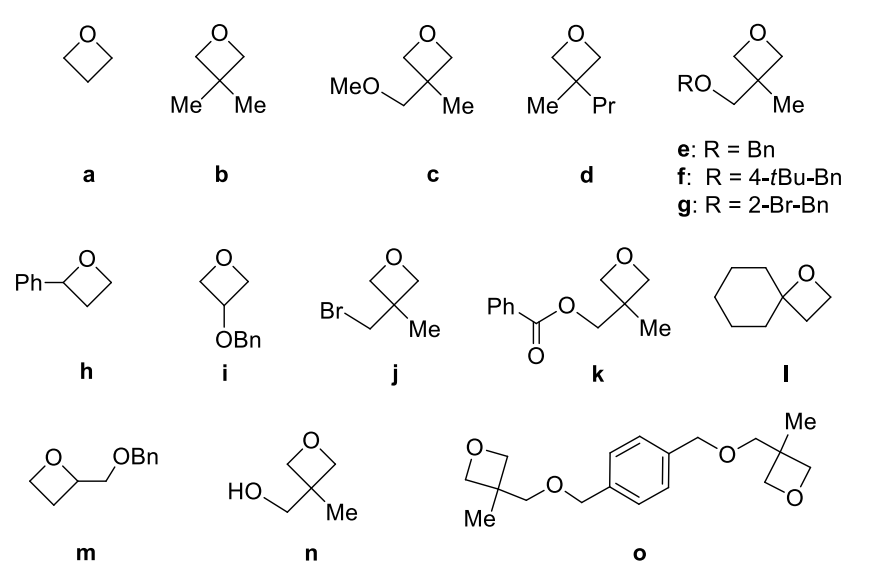

Figure 1. Oxetane substrates a-o probed in the screening and scoping studies. Bn stands for benzyl, Ph for phenyl and Pr for propyl.

\section{Results and Discussion}

The starting materials for the coupling reactions (i.e., oxetanes a-o; Figure 1) were prepared using known, improved or original methods (see Experimental Section and Supporting Information for details) for compounds $\mathbf{c}-\mathbf{m}$ and $\mathbf{o}$ whereas oxetanes $\mathbf{a}, \mathbf{b}$ and $\mathbf{n}$ were commercially purchased. Analytical data and relevant NMR spectra of these oxetane substrates are reported in the Supporting Information.

In order to assess the suitability of aminotriphenolate complexes to selectively mediate the coupling between oxetanes and $\mathrm{CO}_{2}$ towards $6 \mathrm{MCCs}$, we first considered the use of various $\mathrm{Fe}$ (III) and $\mathrm{Al}$ (III) complexes, 3,3'-dimethyloxetane (b, Figure 1 ) as substrate and based on our previous experience with oxetane $/ \mathrm{CO}_{2}$ coupling reactions TBAX (TBA = tetrabutyl-ammonium; $\mathrm{X}=\mathrm{Br}, \mathrm{I}$ ) as a nucleophilic additive (Table 1).

Table 1. Results of the screening stage using 3,3'dimethyloxetane $\mathbf{b}$ and $\mathrm{CO}_{2}$ under various conditions. ${ }^{[a]}$ 

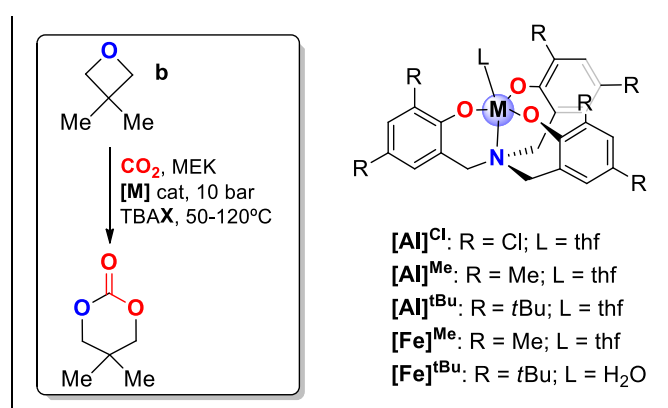

\begin{tabular}{|lllll|} 
Entry & Cat. & Co-cat & $\mathrm{T}$ & Yield \\
& {$[\mathrm{mol} \%]$} & {$[\mathrm{mol} \%]$} & {$\left[{ }^{\circ} \mathrm{C}\right]$} & {$[\%]^{[\mathrm{b}, \mathrm{c}]}$} \\
\hline 1 & - & TBAB $(5.0)$ & 75 & $<1$
\end{tabular}

$2 \quad \mathbf{A l}^{\mathrm{Cl}}(2.5) \quad \operatorname{TBAB}(5.0) \quad 75 \quad 20$

$3 \quad \mathbf{A l}^{\mathrm{Me}}(2.5) \quad \operatorname{TBAB}(5.0) \quad 75 \quad 37(50)^{[\mathrm{d}]}$

$4 \quad \mathbf{A l}^{\mathbf{t B u}}(2.5) \quad \operatorname{TBAB}(5.0) \quad 75 \quad 83(94)^{[\mathrm{d}]}$

$5 \quad \mathbf{F e}^{\mathbf{M e}}(2.5) \quad \operatorname{TBAB}(5.0) \quad 75 \quad 25$

$6 \quad \mathbf{F e}^{\mathrm{tBu}}(2.5) \quad \operatorname{TBAB}(5.0) \quad 75 \quad 26$

$7 \quad \mathbf{A l}^{\mathrm{Cl}}(2.5) \quad$ TBAI (5.0) $75 \quad 7(10)^{[\mathrm{d}]}$

$\begin{array}{lllll}8 & \mathbf{A l}^{\mathrm{Me}}(2.5) & \text { TBAI (5.0) } & 75 & 15(34)^{[\mathrm{d}]}\end{array}$

$9 \quad \mathbf{A l}^{\mathbf{t B u}}(2.5) \quad$ TBAI (5.0) $\quad 75 \quad 51$

$\begin{array}{lllll}10 & \mathbf{A l}^{\mathbf{t B u}}(1.0) & \mathrm{TBAB}(2.0) & 75 & 27\end{array}$

$\begin{array}{lllll}11 & \mathbf{A l} & \\ \end{array}$

$12 \quad \mathbf{A l}^{\mathbf{t B u}}(2.5) \quad$ TBAB (2.5) $75 \quad 71$

$13 \quad \mathbf{A l}^{\mathbf{t B u}}(2.5) \quad \operatorname{TBAB}(5.0) \quad 50 \quad<1$

$14 \quad \mathbf{A l}^{\mathrm{tBu}}(2.5) \quad \operatorname{TBAB}(5.0) \quad 65 \quad 71$

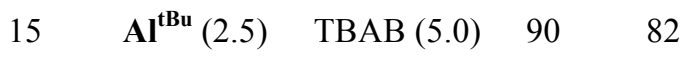

$\begin{array}{lllll}16 & \mathbf{A l}^{\mathbf{t B u}} & (2.5) & \text { TBAB (5.0) } & 100 \quad 80\end{array}$

$17 \quad \mathbf{A l}^{\mathbf{t B u}}(2.5) \quad \operatorname{TBAB}(5.0) \quad 120 \quad 70^{[\mathrm{e}]}$

[a] General conditions: $2 \mathrm{mmol}$ substrate, $p\left(\mathrm{CO}_{2}\right)=10$ bar, MEK (1 mL), $18 \mathrm{~h}, \operatorname{MEK}(1 \mathrm{~mL})$ as solvent. [b] NMR yield based on the use of mesitylene as internal standard. [c] Selectivity for the cyclic carbonate in each case $>98 \%$ as determined by ${ }^{1} \mathrm{H}$ NMR $\left(\mathrm{CDCl}_{3}\right)$. [d] In parentheses the NMR yield after $60 \mathrm{~h}$. [e] Only polyether product observed.

Our first experiments were done under relatively mild conditions (75으, 10 bar) using MEK (methylethyl ketone) as solvent to favour the formation of the desired product (Table 1, entries 2-6). Interestingly, under these conditions the Al-complexes (see also Scheme 1 ) having chloro or methyl substituents $\left(\mathbf{A l}^{\mathrm{Cl}}\right.$ and $\mathbf{A} \mathbf{I}^{\mathrm{Me}}$ ) performed more poorly when compared to the one comprising of bulky $t \mathrm{Bu}$ groups $\left(\mathbf{A l}^{\mathrm{tBu}}\right)$ that showed the highest (NMR) yield of cyclic carbonate (83\%) with excellent chemo-selectivity towards the $6 \mathrm{MCC}$ (>98\%). Both Fe-complexes ( $\mathrm{Fe}^{\mathrm{Me}}$ and $\mathrm{Fe}^{\mathrm{tBu}}$ ) showed inferior activity and gave much lower 6MCC yield under these conditions (entries 5 and 6). Changing the anion in the ammonium salt (entries 79) from bromide to iodide had a pronounced negative effect on the observed yield, and the most optimal ratio between the best performing $\mathrm{Al}$-complex $\mathrm{Al}^{\mathrm{tBu}}$ and the nucleophilic co-catalyst TBAB turned out to be 2.5/5.0 mol\% (cf., entries 4 and 10-12). Next we turned our attention to the influence of the reaction temperature on the product distribution (cyclic versus poly-carbonate) and the observed yield of the $6 \mathrm{MCC}$ target (entries 4 and 13-17). At 50을 there is hardly any product formation in line with the more difficult activation of oxetane substrates compared to oxiranes. Upon raising the temperature ( $c f$., entry 4), the most optimal one seems to be $75^{\circ} \mathrm{C}$ with no further increase in yield observed beyond this temperature. At $120 \circ \mathrm{C}$, the only product that was observed was (presumably) a polyether as testified by the resonance observed around $3.5 \mathrm{ppm}$ in the ${ }^{1} \mathrm{H}$ NMR spectrum of the crude mixture. A longer reaction time improved the yield of the carbonate from 83 to $94 \%$ while keeping high chemo-selectivity (entry 4).

Note that the sole use of TBAB (entry 1 ) gave only trace amounts of product emphasizing the crucial role of $\mathbf{A l}^{\mathrm{tBu}}$ in obtaining high yield and high chemoselectivity. Interestingly, the optimal catalyst structure 
$\mathrm{Al}^{\mathrm{tBu}}$ is markedly different from the one being optimal for cyclic carbonate formation $\left(\mathbf{A l}^{\mathbf{C l}}\right)$ for oxirane $/ \mathrm{CO}_{2}$ coupling reactions. ${ }^{[15 a-c]}$ The optimal reaction conditions [75ㅇ, 10 bar, $\mathbf{A l}^{\text {tBu }}$ (2.5 mol\%), TBAB (5 mol\%), MEK as solvent] were then taken as starting point to investigate the scope of this catalytic process (Figure 1).

We examined a series of oxetane substrates having different substitution patterns (Figure $2 ; R^{1}-R^{3}$ ). As expected, the most simple 6MCC $1\left(R^{1}=R^{2}=R^{3}=H\right)$ could be easily produced in high yield (92\%). Oxetanes with various substitution patterns in the 3-positions of the oxetane ring could also be conveniently converted into their 6MCCs. Several (functional) groups were tolerated including ether $(\mathbf{3}, 5-7,9,13,15)$, alkyl halide (10), aryl-bromide (7) and ester (11) groups. Of particular note are the syntheses of 6MCCs 8,12 and $\mathbf{1 3}$ having the substitution in the 2-position of the oxetane ring: such $6 \mathrm{MCC}$ s have been seldom reported. Whereas $\mathbf{8}$ and $\mathbf{1 3}$ were isolated in high yield $(92 \%$ and $85 \%)$ under mild conditions, for the sterically challenging substrate having a 2-cyclohexyl substituent the catalytic protocol required sterically less demanding catalyst components (Al $\left.{ }^{\mathrm{Me}}, \mathrm{TBAC}\right)$ and harsher reaction conditions (110ㅇ, 40 bar) which resulted in a reasonable yield for $\mathbf{1 2}$ (61\%). For some of the oxetane substrates the use of PPNI as nucleophile in combination with higher reaction temperatures $\left(80-110^{\circ} \mathrm{C}\right)$ proved to be more productive. The formation of carbonate 3 could be best achieved with the Fe-based catalyst $\left[\mathrm{Fe}^{\mathrm{tBu}}\right]$ giving $75 \%$ NMR yield ( $59 \%$ isolated) after $40 \mathrm{~h}$. Of further note is the formation of unprotected carbonate $\mathbf{1 4}$ (63\%); previous literature describing this compound indicated the decomposition of this compound at elevated temperatures via intramolecular rearrangement. ${ }^{[16]}$
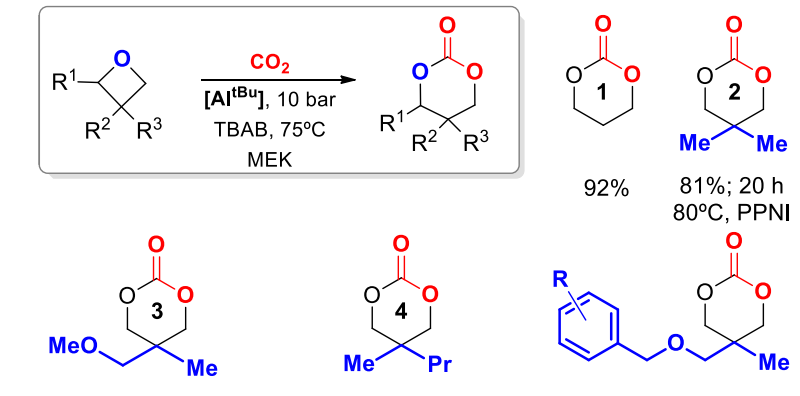

$59 \% ; 40 \mathrm{~h} ; 110^{\circ} \mathrm{C} ; 40 \mathrm{bar}$ $\left[\mathrm{Fe}^{\mathrm{tBu}}\right] / \mathrm{PPNI}=5 / 10 \mathrm{~mol} \%$

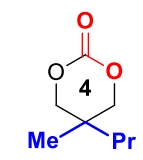

$\mathbf{R}$

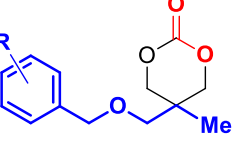

$70 \% ; 24 \mathrm{~h} ; 110^{\circ} \mathrm{C}$ 40 bar, $10 \mathrm{~mol} \%$ PPNI

5: $\mathrm{R}=\mathrm{H}, 81 \%$ 6: $R=4-\mathrm{tBu}, 87 \%(24 \mathrm{~h})$ 7: $\mathrm{R}=2-\mathrm{Br}, 49 \%$
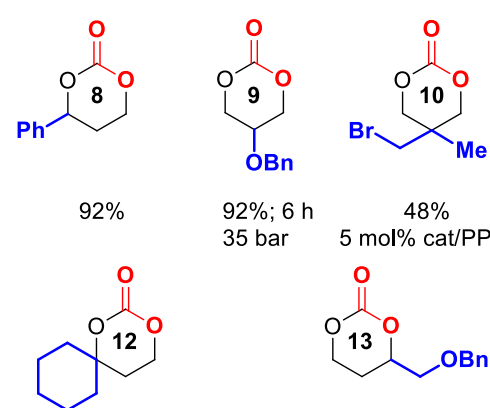

$48 \%$

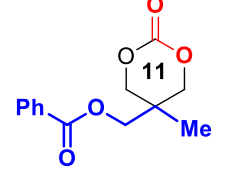

$65 \% ; 110^{\circ} \mathrm{C} ; 40$ bar 35 bar $5 \mathrm{~mol} \% \mathrm{cat} / \mathrm{PPNI} \quad 65 \mathrm{~h} ; 5 / 10 \mathrm{~mol} \% \mathrm{cat} / \mathrm{PPNI}$

$61 \% ; 110^{\circ} \mathrm{C} ; 40$ bar $60 \mathrm{~h} ; 5 / 10 \mathrm{~mol} \%\left[\mathrm{Al}^{\mathrm{Me}}\right] / \mathrm{TBAC}$
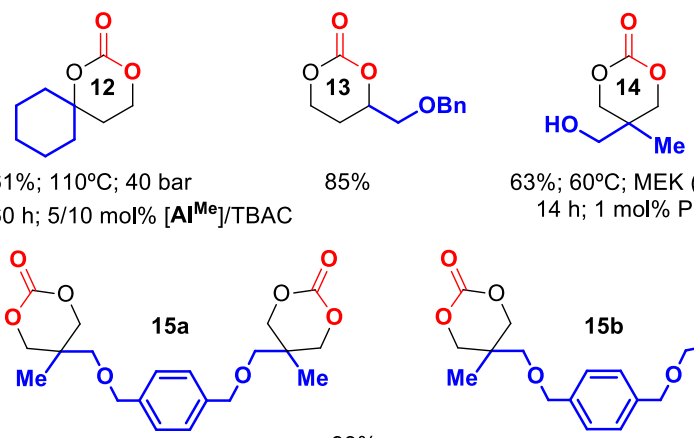

$63 \% ; 60^{\circ} \mathrm{C}$; MEK $(2 \mathrm{~mL})$ $14 \mathrm{~h} ; 1 \mathrm{~mol} \% \mathrm{PPNI}$

0

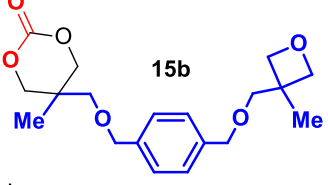

$85 \%$ sel, $75 \%$ isolated(15a)

$15 \%$ sel., $13 \%$ isolated $(\mathbf{1 5 b})$

Figure 2. Use of various substituted oxetanes (box) in the coupling reactions with $\mathrm{CO}_{2}$ affording $6 \mathrm{MCCs}$

1-15. Reaction conditions (unless stated otherwise): $75 \circ \mathrm{C}, 10 \mathrm{bar}, 2.5 \mathrm{~mol} \%\left[\mathbf{A l}^{\mathrm{tBu}}\right], 5.0 \mathrm{~mol} \%$ TBAB, $1 \mathrm{~mL}$ MEK, $18 \mathrm{~h}$. In all cases the chemo-selectivity for the $6 \mathrm{MCC}$ was $>95 \%$ as determined by ${ }^{1} \mathrm{H}$ NMR. TBAC $=$ tetrabutylammonium chloride. Reported here are the yields of the isolated products.

We were pleased to find that application of a moderate reaction temperature $\left(60^{\circ} \mathrm{C}\right)$ gave clean access to $\mathbf{1 4}$ in good selectivity (NMR yield: 93\%), with partial loss of product being ascribed to the isolation procedure. Both bis- and mono-carbonate products $15 \mathrm{a}$ and $15 \mathrm{~b}$, respectively, could be easily isolated, and under optimized conditions the yield for 15a was $75 \%$. Bis-carbonate 15 a is potentially an interesting candidate for ROP as two propagating polymer chains 
may be induced simultaneously having rigid interconnecting linkers. All 6MCCs were fully characterized (see Supporting Information) and the X-ray molecular structures for $\mathbf{6}$ and $\mathbf{9}$ (see Supporting Information), and $\mathbf{1 1}$ and 15a (Figure 3) have also been determined. ${ }^{[17]}$

Particularly useful are the IR spectral features for the $6 \mathrm{MCC}$, as they provide diagnostic $\mathrm{C}=\mathrm{O}$ absorption bands. Typically, the carbonyl stretching frequency is observed in the range $1720-1750 \mathrm{~cm}^{-1}$ which is at much lower wavenumbers when compared to fivemembered carbonates that usually show $\mathrm{C}=\mathrm{O}$ stretching frequencies beyond $1760 \mathrm{~cm}^{-1}$.
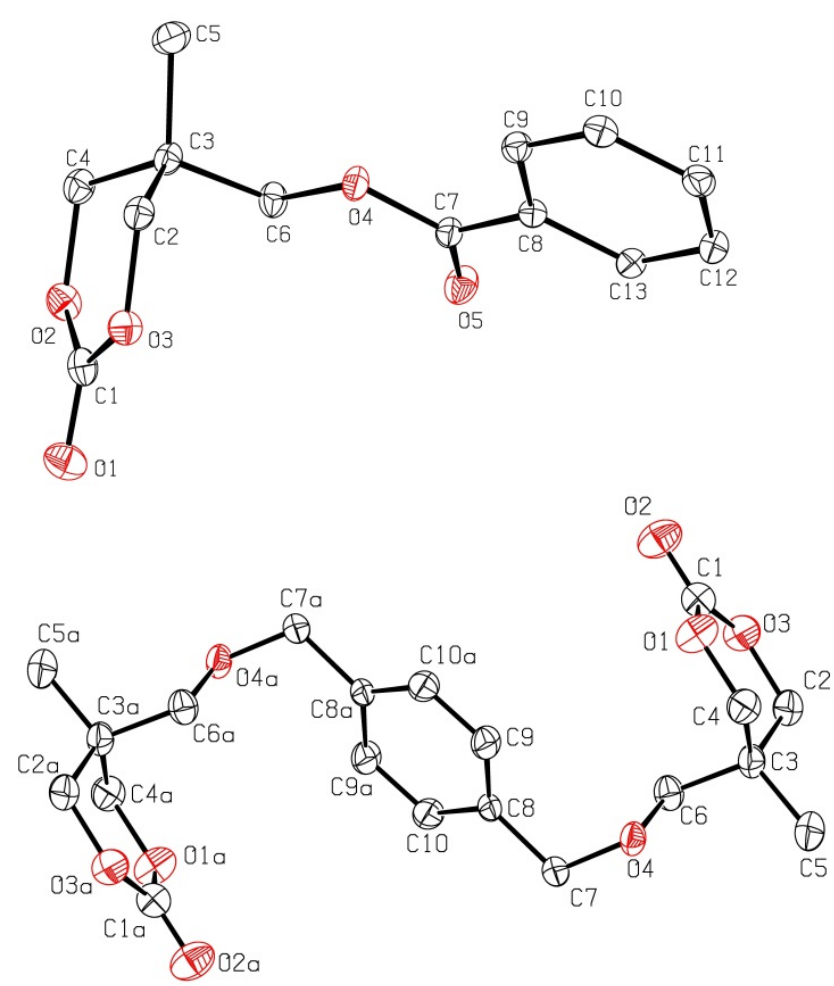

Figure 3. X-ray molecular structures determined for 6MCCs 11 (top) and 15a (below). Selected bond lengths $(\AA)$ and angles(-9) for 11 : $\mathrm{C}(1)-\mathrm{O}(1)=$ 1.2081(19), $C(1)-O(2)=1.3366(18), C(1)-O(3)=$ 1.3365(18), $C(7)-O(4)=1.3529(16), C(7)-O(5)=$ 1.2087(18); O(2)-C(1)-O(3) = 120.24(13), O(1)-C(1)$\mathrm{O}(2)=119.93(14), \mathrm{O}(4)-C(7)-\mathrm{O}(5)=122.40(12)$;
Selected bond lengths ( $\AA$ ) and angles() for 15a: $C(1)$ $\mathrm{O}(1)=1.332(3), C(1)-O(2)=1.205(3), C(1)-O(3)=$ $1.322(3) ; \mathrm{O}(1)-\mathrm{C}(1)-\mathrm{O}(2)=120.19(19), \mathrm{O}(1)-\mathrm{C}(1)-\mathrm{O}(3)=$ $120.4(2), O(2)-C(1)-O(3)=119.4(2)$.

The use of oxetane precursors having pendent hydroxyl or amino substituents was then also studied in the context of $6 \mathrm{MCC}$ formation. First, we probed oxetane $\mathbf{p}$ (Figure 4 ) as substrate and used the optimized conditions (75으, 10 bar, $\mathrm{Al}^{\mathrm{tBu}}$, TBAB, MEK, $18 \mathrm{~h}$ ) from the previous scope phase to study the formation of the carbonate product. Full conversion of $\mathbf{p}$ was observed in the ${ }^{1} \mathrm{H}$ NMR of the crude product, and the cyclic carbonate was isolated in $85 \%$ yield. Detailed NMR analysis, however, revealed that the five-membered carbonate $\mathbf{1 6}$ had been isolated and not the targeted 6MCC. Intrigued by this result, we then conducted a number of control experiments to explain this observation. Surprisingly, the reaction at $25^{\circ} \mathrm{C}$ also proceeded smoothly with quantitative conversion (18 h) of $\mathbf{p}$ into $\mathbf{1 6}$. As the nucleophilic ring-opening of oxetanes in general takes place at somewhat elevated temperatures with an onset at temperature $>50 \circ \mathrm{C}^{[15 \mathrm{~d}]}$ we then examined whether the addition of the bromide nucleophile was required for conversion of $\mathbf{p}$. We found that formation of $\mathbf{1 6}$ takes place in the absence of TBAB under extremely mild conditions (25C, NMR yield $50 \%, 18 \mathrm{~h}$ ). These results seem to indicate that the formation of the carbonate product $\mathbf{1 6}$ does not necessarily proceed via the established mechanism that involves nucleophilic ring-opening at the 2-position of the oxetane but instead can follow a different pathway. In the absence of the complex [A $\left.{ }^{\mathrm{tBu}}\right]$ no conversion takes place stressing the imperative role of the Alcomplex in the formation of $\mathbf{1 6}$. Previously the group of Minakata reported on the formation of highly functional organic carbonates and carbamates through the reaction of $\mathrm{CO}_{2}$ with unsaturated alcohols ${ }^{[18]}$ or amines ${ }^{[19]}$ that were converted under very mild conditions using a stoichiometric amount of $t \mathrm{BuOl}$ as a reagent. These contributions nicely 
demonstrated that rather unstable carbonic acid intermediates can be conveniently trapped by the hypoiodite reagent mediating an intramolecular cyclization process that involves the unsaturated part of the substrate and leading to five- or six-membered heterocycles.

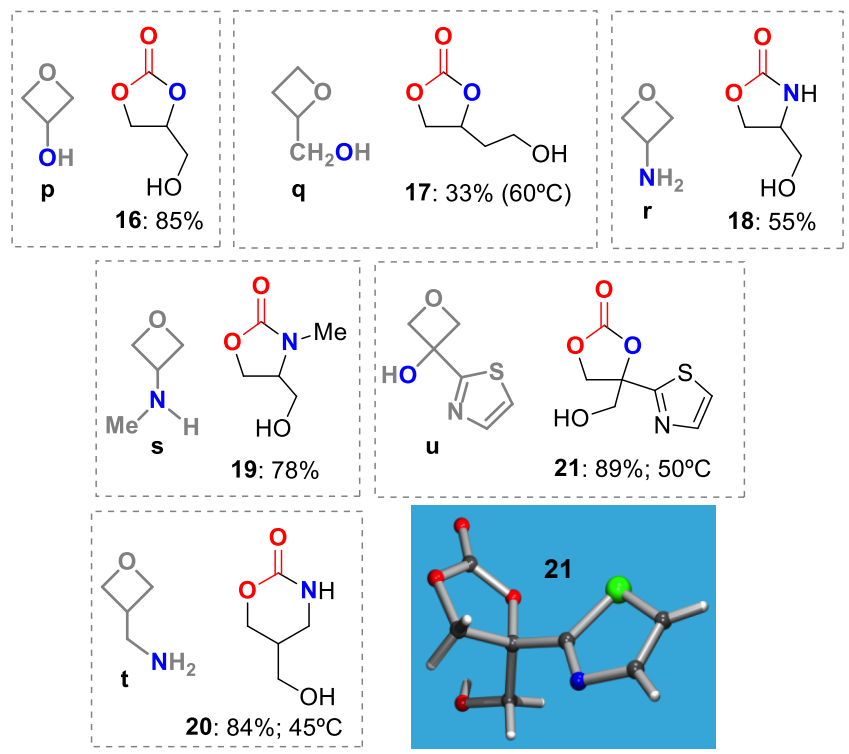

Figure 4. Substrate scope using various amino- and hydroxy-substituted oxetanes $\mathbf{p}-\mathbf{u}$ in the coupling reactions with $\mathrm{CO}_{2}$ affording organic carbonates/carbamates 16-21. Reaction conditions (unless stated otherwise): 25으, $10 \mathrm{bar}, 2.5 \mathrm{~mol} \%$ $\left[\mathrm{Al}^{\mathrm{tBu}}\right], 5.0 \mathrm{~mol} \%$ TBAB, $1 \mathrm{~mL}$ MEK, $18 \mathrm{~h}$. In all cases (except for 17) the NMR yield was $>95 \%$.

Based on all observations we propose that fivemembered carbonate $\mathbf{1 6}$ is formed through the formation of an intermediate carbonic acid that is stabilized/activated by the Al-complex $\left[\mathbf{A}{ }^{\mathbf{t B u}}\right]$ acting as a bifunctional entity. The Al-centre coordinates the linear carbonate fragment after initial reaction of $\mathbf{p}$ with $\mathrm{CO}_{2}$, and the carbonic acid proton is abstracted by one of the phenolate anions of the aminotriphenolate ligand (Scheme 2). This allows for the linear carbonate to act as an internal nucleophile ${ }^{[20]}$ able to ring-open the oxetane after which the product, glycidol carbonate 16, is formed. Similar non-innocent ligand behaviour in other $\mathrm{Al}(\mathrm{III})$ complexes has been recently reviewed. ${ }^{[21]}$ When the alcohol function in $\mathbf{p}$ is benzyl-protected (cf., the synthesis of $\mathbf{9}$, Figure 2) no five-membered carbonate could be detected implying an important role for the unprotected alcohol function in the formation of $\mathbf{1 6}$ in line with the proposed mechanism in Scheme 2. Comparable observations were done for benzylprotected oxetane $\boldsymbol{m}$ in the synthesis of 6 MCC 13 , see Figure 1.

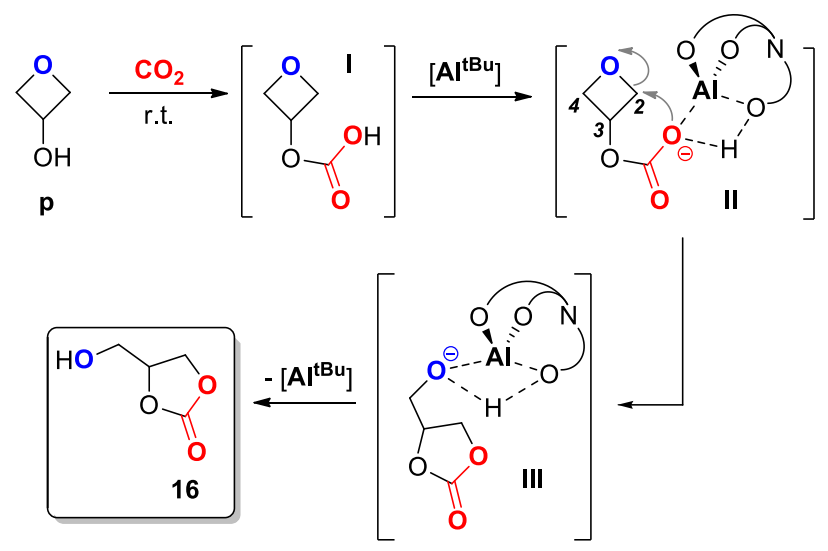

Scheme 2. Proposed mechanism for the formation of carbonate $\mathbf{1 6}$ through intermediates I-III. In the presence of TBAB, the bromide nucleophile is supposed to first attack the oxetane ring in II after which an intramolecular $S_{N} 2$ reaction involving the carbonate fragment takes place on the oxetane C2 carbon centre more facile at lower temperature.

To further support the presence of a carbonic acid derived intermediate, a series of hydroxyl/aminoterminated oxetanes ( $\mathbf{q}-\mathbf{u}$, Figure 4$)$ were then subjected to similar reaction conditions used to convert $\mathbf{p}$ into $\mathbf{1 6}$. In all cases the formation of the cyclic carbonate/carbamate products 16-21 proceeded under very mild conditions (25-60ㅇ) with NMR yields exceeding 95\% (except for $17 ; 33 \%) .{ }^{[22]}$ In the case where the intramolecular ring-closure first involved an attack on a tertiary carbon centre (i.e. for 
the conversion of oxetane q) a slightly higher reaction temperature was required to obtain high conversion. Both amino- and hydroxy-terminated substrates showed similar behaviour giving rise to either cyclic carbonate or carbamate formation. The presence of a secondary amine function in oxetane $\mathbf{s}$ allowed for formation of the $\mathrm{N}$-methyl oxazolidinone product at room temperature. The presence of another type of heteroatom in the oxetane structure allows for further differentiation of the proposed mechanism in Scheme 2 and the one that relates to conventional initial ring-opening of the oxetane followed by $\mathrm{CO}_{2}$ insertion and ring-closing. Thus, the presence of the $\mathrm{N}$ atom in the five- and six-membered ring systems of carbamates 18-20 is further testament that the hydroxyl- and amino-functionalized oxetanes first react with $\mathrm{CO}_{2}$ to form intermediate carbonic or carbamic acid derivatives that activate the oxetane for ring-opening by the in situ produced nucleophile. The structure for the five-membered, thiazole-based cyclic carbonate $\mathbf{2 1}$ that would result from an intramolecular attack of a carbonic acid derivative was confirmed by X-ray crystallography (Figure 4, blue box ${ }^{[17]}$ in line with the proposed mechanism for the formation of the carbonates/carbamates 16-21.

\section{Conclusions}

In summary, we here present the first general and selective catalytic methodology for the efficient coupling of oxetanes and $\mathrm{CO}_{2}$ giving a range of functional 6MCCs in fair to good yields. This method is further characterized by the use of catalysts based on cheap, abundant and non-toxic metal complexes showing unparalleled reactivity with high potential in the preparation of 6MCCs that are of use in synthetic and polymer chemistry. The first $\mathrm{CO}_{2}$ /oxetane couplings at ambient temperature conditions are reported herein with a crucial role for an intermediate carbonic acid derivative. Our future focus is on the preparation of suitable $6 \mathrm{MCC}$ monomers that are preferentially bio-sourced and allow for post- modification of functionalized polymers that are obtained through ROP technology.

\section{Experimental Section}

\section{General Information}

Both the ligands ${ }^{[23]}$ and metal catalysts (see Table 1) ${ }^{[15 c]}$ were prepared according to previously reported procedures. $1 \mathrm{H}$ and $13 \mathrm{C}$ NMR spectra were recorded on a Bruker AV-300, AV-400 or AV-500 spectrometer. Mass spectrometric analysis and $X$-ray diffraction studies were performed by the Research Support Group at the ICIQ (Tarragona). Carbon dioxide was purchased from PRAXAIR and used without further purification. Solvents used in the synthesis of the complexes were dried using an Innovative Technology PURE SOLV solvent purification system.

\section{Preparation of Oxetane Precursors}

Oxetanes $\mathbf{a}, \mathbf{b}, \mathbf{n}$ and $\mathbf{p}-\mathbf{u}$ are commercially available and were used as received. Oxetanes $\mathbf{e}^{[11]}, \mathbf{h}^{[24]}, \mathbf{I}^{[24]}$ and $\mathbf{j}^{[25]}$ were prepared according to modified literature procedures. Oxetanes $\mathbf{c}^{[11]}$ and $\mathbf{d}^{[26]}$ were prepared according to previously reported procedures. Oxetanes $\mathbf{f}, \mathbf{g}, \mathbf{i}, \mathbf{k}, \mathbf{m}$ and $\mathbf{o}$ were prepared in a similar way as oxetane $\mathbf{e}$.

\section{Typical Catalytic Coupling between Substituted Oxetanes and $\mathrm{CO}_{2}$}

The respective oxetane, Al-complex, co-catalyst and 1 $\mathrm{mL}$ of MEK (2-butanone) were charged into a $30 \mathrm{~mL}$ stainless steel autoclave. The autoclave was then subjected to three cycles of pressurization and depressurization with carbon dioxide ( 5 bar), before final stabilization of the pressure to 10 bar. The autoclave was sealed and heated to the required temperature and left stirring. At the end of the reaction an aliquot of the resulting mixture was taken and the conversion/yield determined by means of ${ }^{1} \mathrm{H}$ NMR spectroscopy using $\mathrm{CDCl}_{3}$ as the solvent and mesitylene as internal standard. The pure cyclic 
carbonate product was then isolated by column chromatography and the solvent removed under vacuum. The identities of the cyclic carbonate products were confirmed by comparison to literature data or where unavailable, characterized by ${ }^{1} \mathrm{H} /{ }^{13} \mathrm{C}$ NMR, IR and HRMS. In the case of the carbonates 6, 9, 11, 15a and 21 the molecular structures were further supported by $\mathrm{X}$-ray diffraction studies.

\section{Catalytic and Analytical Details for the Cyclic Carbonate Structures}

1,3-dioxan-2-one $(1)^{[15 b]}$

[Al ${ }^{\mathrm{tBu}}$ ]: 2.5 mol\%; [TBAB]: 5 mol\%; T: 75ㅇ, $p\left(\mathrm{CO}_{2}\right): 10$ bar, time: $18 \mathrm{~h}$; conversion: $99 \%$. Isolated by column chromatography (EtOAc:hexane 1:8 to $1: 1 \mathrm{v} / \mathrm{v}$ ) in $92 \%$ yield. ${ }^{1} \mathrm{H} \mathrm{NMR}\left(300 \mathrm{MHz}, \mathrm{CDCl}_{3}\right): d=4.40(\mathrm{t}, J=5.7 \mathrm{~Hz}$, $4 \mathrm{H}), 2.02-2.19(\mathrm{~m}, 2 \mathrm{H}) ;{ }^{13} \mathrm{C}\left\{{ }^{1} \mathrm{H}\right\} \mathrm{NMR}\left(75 \mathrm{MHz}, \mathrm{CDCl}_{3}\right)$ : $d=148.60,68.07,21.65$; IR (neat): $1725 \mathrm{~cm}^{-1}(\mathrm{C}=0)$.

\section{5,5-dimethyl-1,3-dioxan-2-one (2) ${ }^{[15 b]}$}

[Al ${ }^{\mathrm{tBu}}$ ]: 2.5 mol\%; [PPNI]: $2.5 \mathrm{~mol} \%$; T: 75C, $p\left(\mathrm{CO}_{2}\right): 10$ bar, time: $20 \mathrm{~h}$; conversion: $96 \%$. Isolated by column chromatography (EtOAc:hexane $1: 2$ to $1: 1 \mathrm{v} / \mathrm{v}$ ) in $81 \%$ yield. ${ }^{1} \mathrm{H}$ NMR $\left(400 \mathrm{MHz}, \mathrm{CDCl}_{3}\right): d=4.09(\mathrm{~s}, 4 \mathrm{H}), 1.14$ $(\mathrm{s}, 6 \mathrm{H}) ;{ }^{13} \mathrm{C}\left\{{ }^{1} \mathrm{H}\right\}$ NMR $\left(75 \mathrm{MHz}, \mathrm{CDCl}_{3}\right): d=148.11$, 77.49, 28.45, 21.12; IR (neat): $1736 \mathrm{~cm}^{-1}(\mathrm{C}=0)$.

\section{5-(methoxymethyl)-5-methyl-1,3-dioxan-2-one (3) ${ }^{[11]}$}

[Fe ${ }^{\mathrm{tBu}}$ ]: 5 mol\%; [PPNI]: 10 mol\%; T: 110C, $p\left(\mathrm{CO}_{2}\right): 40$ bar, time: $40 \mathrm{~h}$; conversion: $75 \%$. Isolated by column chromatography (EtOAc:hexane 1:4 $\mathrm{v} / \mathrm{v}$ ) in $59 \%$ yield. ${ }^{1} \mathrm{H}$ NMR (400 MHz, [ $\mathrm{D}_{6}$ ] lacetone): $d=4.32(\mathrm{~d}, J=10.6$ $\mathrm{Hz}, 2 \mathrm{H}), 4.18(\mathrm{~d}, \mathrm{~J}=10.6 \mathrm{~Hz}, 2 \mathrm{H}), 3.39(\mathrm{~s}, 2 \mathrm{H}), 3.36(\mathrm{~s}$, $3 \mathrm{H}), 1.08(\mathrm{~s}, 3 \mathrm{H}) ;{ }^{13} \mathrm{C}\left\{{ }^{1} \mathrm{H}\right\}$ NMR (126 MHz, [D $\mathrm{D}_{6}$ ]acetone): $d=147.41,73.63,73.43,58.62,32.65,16.23$; IR (neat): $1742 \mathrm{~cm}^{-1}(\mathrm{C}=0)$.

\section{5-methyl-5-propyl-1,3-dioxan-2-one (4)}

[Al ${ }^{\mathrm{tBu}}$ ]: 2.5 mol\%; [PPNI]: $10 \mathrm{~mol} \%$; $\mathrm{T:} 110 \circ \mathrm{C}, p\left(\mathrm{CO}_{2}\right)$ : 40 bar, time: $24 \mathrm{~h}$; conversion: $73 \%$. Isolated by column chromatography (EtOAc:hexane $1: 1 \mathrm{v} / \mathrm{v}$ ) in $70 \%$ yield. ${ }^{1} \mathrm{H}$ NMR $\left(400 \mathrm{MHz}, \mathrm{CDCl}_{3}\right): d=4.15(\mathrm{~d}, J=$ $10.6 \mathrm{~Hz}, 2 \mathrm{H}$ ), $4.07(\mathrm{~d}, J=10.6 \mathrm{~Hz}, 2 \mathrm{H}), 1.31-1.47$ (m, $4 \mathrm{H}), 1.09(\mathrm{~s}, 3 \mathrm{H}), 0.97(\mathrm{t}, J=6.9 \mathrm{~Hz}, 3 \mathrm{H}) ;{ }^{13} \mathrm{C}\left\{{ }^{1} \mathrm{H}\right\} \mathrm{NMR}$ $\left(75 \mathrm{MHz}, \mathrm{CDCl}_{3}\right): d=148.34,77.46,77.03,76.61$, 76.47, 36.40, 31.13, 18.33, 16.49, 14.54; IR (neat): $1743 \mathrm{~cm}^{-1}(\mathrm{C}=0)$.

\section{5-((benzyloxy)methyl)-5-methyl-1,3-dioxan-2-one $(5)^{[11]}$}

$\left[\mathrm{Al}^{\mathrm{tBu}}\right.$ ]: 2.5 mol\%; [TBAB]: 5 mol\%; $\mathrm{T}: 75 \circ \mathrm{C}, p\left(\mathrm{CO}_{2}\right): 10$ bar, time: $24 \mathrm{~h}$; conversion: $99 \%$. Isolated by column chromatography (EtOAc:hexane 1:8 to $1: 1 \mathrm{v} / \mathrm{v}$ ) in $92 \%$ yield. ${ }^{1} \mathrm{H}$ NMR $\left(400 \mathrm{MHz}, \mathrm{CDCl}_{3}\right): d=7.29-7.42(\mathrm{~m}, 5 \mathrm{H})$, $4.55(\mathrm{~s}, 2 \mathrm{H}), 4.38(\mathrm{~d}, J=10.8 \mathrm{~Hz}, 2 \mathrm{H}), 4.10(\mathrm{~d}, J=10.8$ $\mathrm{Hz}, 2 \mathrm{H}), 3.43(\mathrm{~s}, 2 \mathrm{H}), 1.12(\mathrm{~s}, 3 \mathrm{H}) ;{ }^{13} \mathrm{C}\left\{{ }^{1} \mathrm{H}\right\}$ NMR (101 $\left.\mathrm{MHz}, \mathrm{CDCl}_{3}\right): d=148.25,137.46,128.53,127.96$, 127.59, 73.95, 73.59, 71.10, 33.03, 17.43; IR (neat): $1743 \mathrm{~cm}^{-1}$ (C=O); HRMS (ESI+): calcd. for $\mathrm{C}_{13} \mathrm{H}_{16} \mathrm{O}_{4}: \mathrm{m} / \mathrm{z}$ $=259.0946[\mathrm{M}+\mathrm{Na}]^{+}$; found: 259.0932 .

\section{5-(((4-(tert-butyl)benzyl)oxy)methyl)-5-methyl-1,3- dioxan-2-one (6)}

$\left[\mathrm{Al}^{\mathrm{tBu}}\right.$ ]: $2.5 \mathrm{~mol} \%$; [TBAB]: $5 \mathrm{~mol} \%$; T: 75ㅇ, $p\left(\mathrm{CO}_{2}\right): 10$ bar, time: $24 \mathrm{~h}$; conversion: $93 \%$. Isolated by column chromatography (EtOAc:hexane 1:4 to $1: 1 \mathrm{v} / \mathrm{v}$ ) in $87 \%$ yield. ${ }^{1} \mathrm{H}$ NMR $\left(500 \mathrm{MHz}, \mathrm{CDCl}_{3}\right): d=7.41(\mathrm{~d}, J=8.3 \mathrm{~Hz}$, $2 \mathrm{H}), 7.26(\mathrm{~d}, J=8.3 \mathrm{~Hz}, 2 \mathrm{H}), 4.52(\mathrm{~s}, 2 \mathrm{H}), 4.38(\mathrm{~d}, J=$ $10.9 \mathrm{~Hz}, 2 \mathrm{H}), 4.10(\mathrm{~d}, J=10.8 \mathrm{~Hz}, 2 \mathrm{H}), 3.43(\mathrm{~s}, 2 \mathrm{H})$, $1.35(\mathrm{~s}, 9 \mathrm{H}), 1.13(\mathrm{~s}, 3 \mathrm{H}) ;{ }^{13} \mathrm{C}\left\{{ }^{1} \mathrm{H}\right\} \mathrm{NMR}(126 \mathrm{MHz}$, $\left.\mathrm{CDCl}_{3}\right): d=150.91,148.32,134.52,127.41,125.42$, 74.01, 73.41, 71.16, 34.58, 33.03, 31.38, 17.43; IR (neat): $1771 \mathrm{~cm}^{-1}(\mathrm{C}=0)$; HRMS (ESI+): calcd. for $\mathrm{C}_{17} \mathrm{H}_{24} \mathrm{O}_{4}: m / z=315.1572[\mathrm{M}+\mathrm{Na}]^{+}$; found: 315.1561.

\section{5-(((2-bromobenzyl)oxy)methyl)-5-methyl-1,3- dioxan-2-one (7)}

$\left[\mathbf{A l}^{\mathrm{tBu}}\right.$ ]: $2.5 \mathrm{~mol} \%$; [TBAB]: 5 mol\%; T: 75C, $p\left(\mathrm{CO}_{2}\right): 10$ bar, time: $24 \mathrm{~h}$; conversion: $53 \%$. Isolated by column chromatography (EtOAc:hexane 1:4 to $1: 2 \mathrm{v} / \mathrm{v}$ ) in $49 \%$ yield. ${ }^{1} \mathrm{H}$ NMR $\left(400 \mathrm{MHz}, \mathrm{CDCl}_{3}\right): d=7.58(\mathrm{~m}, 1 \mathrm{H}), 7.41$ 
(m, 1H), $7.35(\mathrm{~m}, 1 \mathrm{H}), 7.20(\mathrm{~m}, 1 \mathrm{H}), 4.61(\mathrm{~s}, 2 \mathrm{H}), 4.42$ (d, $J=10.9 \mathrm{~Hz}, 2 \mathrm{H}), 4.13(\mathrm{~d}, J=10.9 \mathrm{~Hz}, 2 \mathrm{H}), 3.53(\mathrm{~s}$, $2 \mathrm{H}), 1.16(\mathrm{~s}, 3 \mathrm{H}) ;{ }^{13} \mathrm{C}\left\{{ }^{1} \mathrm{H}\right\}$ NMR $\left(101 \mathrm{MHz}, \mathrm{CDCl}_{3}\right): d=$ 148.16, 136.67, 132.77, 129.40, 129.27, 127.48, 123.06, 73.92, 72.98, 71.61, 33.13, 17.50; IR (neat): $1740 \mathrm{~cm}^{-1}$ (C=O); HRMS (ESI+): calcd. for $\mathrm{C}_{13} \mathrm{H}_{15} \mathrm{BrO}_{4}$ : $\mathrm{m} / \mathrm{z}=337.0051[\mathrm{M}+\mathrm{Na}]^{+}$; found: 337.0049 .

\section{4-phenyl-1,3-dioxan-2-one (8) ${ }^{[27]}$}

[AI ${ }^{\mathrm{tBu}}$ ]: 2.5 mol\%; [TBAB]: 5 mol\%; T: 75으, $p\left(\mathrm{CO}_{2}\right): 10$ bar, time: $18 \mathrm{~h}$; conversion: $96 \%$. Isolated by column chromatography (EtOAc:hexane 1:2 to $1: 1 \mathrm{v} / \mathrm{v}$ ) in $92 \%$ yield. ${ }^{1} \mathrm{H}$ NMR (500 MHz, [ $\left.\mathrm{D}_{6}\right]$ acetone): $d=7.38-7.50$ $(\mathrm{m}, 5 \mathrm{H}), 5.69(\mathrm{~m}, 1 \mathrm{H}), 4.63(\mathrm{~m}, 1 \mathrm{H}), 4.49(\mathrm{~m}, 1 \mathrm{H}), 2.45$ $(\mathrm{m}, 1 \mathrm{H}), 2.26-2.36(\mathrm{~m}, 1 \mathrm{H}) ;{ }^{13} \mathrm{C}\left\{{ }^{1} \mathrm{H}\right\}$ NMR $(126 \mathrm{MHz}$, [ $\mathrm{D}_{6}$ ] acetone): $d=148.42,139.59,129.06,128.95$, 126.30, 80.36, 67.49; IR (neat): $1742 \mathrm{~cm}^{-1}(\mathrm{C}=0)$; HRMS (ESI+): calcd. for $\mathrm{C}_{10} \mathrm{H}_{10} \mathrm{O}_{3}: \mathrm{m} / z=201.0528$ $[\mathrm{M}+\mathrm{Na}]^{+}$; found: 201.0522.

\section{5-(benzyloxy)-1,3-dioxan-2-one (9) ${ }^{[28]}$}

$\left[\mathrm{Al}^{\mathrm{tBu}}\right.$ ]: $2.5 \mathrm{~mol} \%$; [TBAB]: 5 mol\%; $\mathrm{T}: 75 \circ \mathrm{C}, p\left(\mathrm{CO}_{2}\right): 35$ bar, time: $6 \mathrm{~h}$; conversion: $99 \%$. Isolated by column chromatography (EtOAc:hexane 1:4 to 1:1) in $92 \%$ yield. ${ }^{1} \mathrm{H}$ NMR (400 MHz, [ $\mathrm{D}_{6}$ ] acetone): $d=7.29-7.46$ $(\mathrm{m}, 5 \mathrm{H}), 4.74(\mathrm{~s}, 2 \mathrm{H}), 4.65(\mathrm{~d}, J=11.2 \mathrm{~Hz}, 2 \mathrm{H}), 4.55(\mathrm{~d}$, $J=11.4 \mathrm{~Hz}, 2 \mathrm{H}), 4.12(\mathrm{~m}, 1 \mathrm{H}) ;{ }^{13} \mathrm{C}\left\{{ }^{1} \mathrm{H}\right\} \mathrm{NMR}(101 \mathrm{MHz}$, $\left[\mathrm{D}_{6}\right.$ ] acetone): $d=147.21,137.98,128.31,127.64$, 70.02, 69.66, 66.79; IR (neat): $1731 \mathrm{~cm}^{-1}$ ( $\mathrm{C}=0$ ); HRMS (ESI+): calcd. for $\mathrm{C}_{11} \mathrm{H}_{12} \mathrm{O}_{4}: \mathrm{m} / \mathrm{z}=231.0633[\mathrm{M}+\mathrm{Na}]^{+}$; found: 231.0633.

\section{5-(bromomethyl)-5-methyl-1,3-dioxan-2-one (10) ${ }^{[29]}$}

$\left[\mathbf{A l}^{\mathrm{tBu}}\right.$ ]: 5 mol\%; [PPNI]: 5 mol\%; T: 75ㅇ, $p\left(\mathrm{CO}_{2}\right): 10$ bar, time: $18 \mathrm{~h}$; conversion: $55 \%$. Isolated by column chromatography (EtOAc:hexane $1: 2$ to $1: 1 \mathrm{v} / \mathrm{v}$ ) in $48 \%$ yield. ${ }^{1} \mathrm{H} \mathrm{NMR}\left(500 \mathrm{MHz}, \mathrm{CDCl}_{3}\right): d=4.37(\mathrm{~d}, J=11.0$ $\mathrm{Hz}, 2 \mathrm{H}), 4.24(\mathrm{~d}, \mathrm{~J}=11.0 \mathrm{~Hz}, 2 \mathrm{H}), 3.48(\mathrm{~s}, 2 \mathrm{H}), 1.23(\mathrm{~s}$, $3 \mathrm{H}) ;{ }^{13} \mathrm{C}\left\{{ }^{1} \mathrm{H}\right\}$ NMR $\left(126 \mathrm{MHz}, \mathrm{CDCl}_{3}\right): d=147.42,74.22$, $35.48,32.72$, 18.56; IR (neat): $1722 \mathrm{~cm}^{-1}$ ( $\mathrm{C}=0$ ); HRMS
(ESI+): calcd. for $\mathrm{C}_{6} \mathrm{H}_{9} \mathrm{BrO}_{3}: m / z=230.9633[\mathrm{M}+\mathrm{Na}]^{+}$; found: 230.9628.

\section{5-Methyl-5-benzoyloxymethyl-1,3-dioxan-2-one} $(11)^{[30]}$

[Al ${ }^{\mathrm{tBu}}$ ]: 5 mol\%; [PPNI]: $10 \mathrm{~mol} \%$; $\mathrm{T}: 110 \circ \mathrm{C}, p\left(\mathrm{CO}_{2}\right): 40$ bar, time: $65 \mathrm{~h}$; conversion: $80 \%$. Isolated by column chromatography (EtOAc:hexane $1: 2$ to $1: 1 \mathrm{v} / \mathrm{v}$ ) in $65 \%$ yield. ${ }^{1} \mathrm{H} N M R\left(400 \mathrm{MHz}, \mathrm{CDCl}_{3}\right): d=8.04(\mathrm{~m}, 2 \mathrm{H}), 7.63$ $(\mathrm{m}, 1 \mathrm{H}), 7.50(\mathrm{~m}, 2 \mathrm{H}), 4.45(\mathrm{~d}, J=11.1 \mathrm{~Hz}, 2 \mathrm{H}), 4.37(\mathrm{~s}$, $2 \mathrm{H}), 4.25(\mathrm{~d}, J=11.0 \mathrm{~Hz}, 2 \mathrm{H}), 1.25(\mathrm{~s}, 3 \mathrm{H}) ;{ }^{13} \mathrm{C}\left\{{ }^{1} \mathrm{H}\right\} \mathrm{NMR}$ $\left(101 \mathrm{MHz}, \mathrm{CDCl}_{3}\right): d=165.96,147.65,133.61,129.62$, 129.12, 128.64, 73.68, 65.52, 32.60, 17.41; IR (neat): $1727,1718 \mathrm{~cm}^{-1}$ (C=O); HRMS (ESI+): calcd. for $\mathrm{C}_{13} \mathrm{H}_{14} \mathrm{O}_{5}: \mathrm{m} / z=273.0739[\mathrm{M}+\mathrm{Na}]^{+}$; found: 273.0739 . 


\section{1,3-Dioxaspiro[5.5] undecan-2-one (12) ${ }^{[9 d]}$}

[Al ${ }^{\mathrm{Me}}$ ]: $5 \mathrm{~mol} \%$; [TBAC]: $10 \mathrm{~mol} \% ; \mathrm{T}: 110 \circ \mathrm{C}, p\left(\mathrm{CO}_{2}\right): 40$ bar, time: $60 \mathrm{~h}$; conversion: $72 \%$. Isolated by column chromatography (EtOAc:hexane 1:3) in $61 \%$ yield. ${ }^{1} \mathrm{H}$ $\operatorname{NMR}\left(500 \mathrm{MHz}, \mathrm{CDCl}_{3}\right): d=4.39-4.44(\mathrm{t}, J=6.0 \mathrm{~Hz}$, $2 \mathrm{H}), 2.00(\mathrm{t}, J=6.0 \mathrm{~Hz}, 2 \mathrm{H}), 1.88-1.96(\mathrm{~m}, 2 \mathrm{H}), 1.76-$ $1.86(\mathrm{~m}, 2 \mathrm{H}), 1.61(\mathrm{~m}, 2 \mathrm{H}), 1.52(\mathrm{~m}, 2 \mathrm{H}), 1.24-1.46(\mathrm{~m}$, $2 \mathrm{H}) ;{ }^{13} \mathrm{C}\left\{{ }^{1} \mathrm{H}\right\}$ NMR $\left(126 \mathrm{MHz}, \mathrm{CDCl}_{3}\right): d=149.27,82.52$, 64.11, 36.59, 31.53, 25.09, 21.54; IR (neat): $1731 \mathrm{~cm}^{-1}$ (C=O); HRMS (ESI+): calcd. for $\mathrm{C}_{9} \mathrm{H}_{14} \mathrm{O}_{3}: \mathrm{m} / \mathrm{z}=$ $193.0841[\mathrm{M}+\mathrm{Na}]^{+}$; found: 193.0833 .

\section{4-((benzyloxy)methyl)-1,3-dioxan-2-one (13)}

[Al ${ }^{\mathrm{tBu}}$ ]: 2.5 mol\%; [TBAB]: 5 mol\%; T: 75으, $p\left(\mathrm{CO}_{2}\right): 10$ bar, time: $18 \mathrm{~h}$; conversion: $99 \%$. Isolated by column chromatography (EtOAc:hexane 1:2 to $1: 1 \mathrm{v} / \mathrm{v}$ ) in $85 \%$ yield. ${ }^{1} \mathrm{H}$ NMR (300 MHz, [ $\left.\mathrm{D}_{6}\right]$ acetone): $d=7.27-7.42$ $(\mathrm{m}, 5 \mathrm{H}), 4.71-4.82(\mathrm{~m}, 1 \mathrm{H}), 4.61(\mathrm{~s}, 2 \mathrm{H}), 4.46(\mathrm{~m}, 2 \mathrm{H})$, $3.70(\mathrm{~d}, J=4.6 \mathrm{~Hz}, 2 \mathrm{H}), 2.09-2.23(\mathrm{~m}, 2 \mathrm{H}) ;{ }^{13} \mathrm{C}\left\{{ }^{1} \mathrm{H}\right\} \mathrm{NMR}$ (75 MHz, [D $\mathrm{D}_{6}$ ]acetone): $d=148.02,138.36,128.24$, 127.51, 127.49, 77.82, 72.91, 71.20, 66.61, 23.58; IR (neat): $1737 \mathrm{~cm}^{-1}(\mathrm{C}=0)$; HRMS (ESI+): calcd. for $\mathrm{C}_{12} \mathrm{H}_{14} \mathrm{O}_{4}: \mathrm{m} / z=245.0790[\mathrm{M}+\mathrm{Na}]^{+}$; found: 245.0793 .

\section{5-(hydroxymethyl)-5-methyl-1,3-dioxan-2-one (14) ${ }^{[9 c]}$}

[AI ${ }^{\mathrm{tBu}}$ ]: $2.5 \mathrm{~mol} \%$; [PPNI]: $1 \mathrm{~mol} \%$; T: 60ㅇ, $p\left(\mathrm{CO}_{2}\right): 10$ bar, $2 \mathrm{~mL}$ MEK, time: $18 \mathrm{~h}$; conversion: 87\%. Isolated by column chromatography using neutral alumina (EtOAc:hexane 1:1) in $63 \%$ yield. ${ }^{1} \mathrm{H}$ NMR $(400 \mathrm{MHz}$, $\left.\mathrm{CDCl}_{3}\right): d=4.37(\mathrm{~d}, J=10.9 \mathrm{~Hz}, 2 \mathrm{H}), 4.13(\mathrm{~d}, J=10.8$ $\mathrm{Hz}, 2 \mathrm{H}), 3.65(\mathrm{~d}, J=4.9 \mathrm{~Hz}, 2 \mathrm{H}), 2.89(\mathrm{t}, J=5.1 \mathrm{~Hz}, 1 \mathrm{H})$, $1.08(\mathrm{~s}, 3 \mathrm{H}) ;{ }^{13} \mathrm{C}\left\{{ }^{1} \mathrm{H}\right\}$ NMR $\left(101 \mathrm{MHz}, \mathrm{CDCl}_{3}\right): d=$ 148.94, 73.83, 63.61, 33.54, 16.72; IR (neat): $1721 \mathrm{~cm}$ ${ }^{1}(\mathrm{C}=0)$.

\section{5,5'-(((1,4-phenylenebis(methylene))-}

bis(oxy))bis(methylene))-bis(5-methyl-1,3-dioxan-2one) (15a)

[Al ${ }^{\mathrm{tBu}}$ ]: 2.5 mol\%; [TBAB]: 5 mol\%; T: 75ㅇ, $p\left(\mathrm{CO}_{2}\right): 10$ bar, time: 24 h; conversion: $93 \%$, selectivity: $85 \%$.
Isolated by column chromatography (EtOAc:hexane $1: 2$ to $1: 1 \mathrm{v} / \mathrm{v}$ ) in $75 \%$ yield. ${ }^{1} \mathrm{H}$ NMR $\left(400 \mathrm{MHz}, \mathrm{CDCl}_{3}\right)$ : $d=7.31(\mathrm{~s}, 4 \mathrm{H}), 4.55(\mathrm{~s}, 4 \mathrm{H}), 4.37(\mathrm{~d}, J=10.8 \mathrm{~Hz}, 4 \mathrm{H})$, $4.11(\mathrm{~d}, J=10.8 \mathrm{~Hz}, 4 \mathrm{H}), 3.43(\mathrm{~s}, 4 \mathrm{H}), 1.13(\mathrm{~s}, 6 \mathrm{H})$; ${ }^{13} \mathrm{C}\left\{{ }^{1} \mathrm{H}\right\}$ NMR $\left(126 \mathrm{MHz}, \mathrm{CDCl}_{3}\right): d=148.17,137.23$, 127.79, 73.89, 73.25, 71.02, 33.02, 17.40; IR (neat): $1755 \mathrm{~cm}^{-1}$ (C=O); HRMS (ESI+): calcd. for $\mathrm{C}_{20} \mathrm{H}_{26} \mathrm{O}_{8}: \mathrm{m} / \mathrm{z}$ $=417.1525[\mathrm{M}+\mathrm{Na}]^{+}$; found: 417.1504 .

\section{5-methyl-5-(((4-)((3-methyloxetan-3-}

yl)methoxy)methyl)benzyl)-oxy)methyl)-1,3-dioxan2-one (15b)

[A ${ }^{\mathrm{tBu}}$ ]: $2.5 \mathrm{~mol} \%$; [TBAB]: $5 \mathrm{~mol} \%$; T: 75으, $p\left(\mathrm{CO}_{2}\right): 10$ bar, time: $24 \mathrm{~h}$; conversion: $93 \%$, selectivity: $15 \%$. Isolated by column chromatography (EtOAc:Hexane $1: 2$ to $1: 1 \mathrm{v} / \mathrm{v}$ ) in $13 \%$ yield. ${ }^{1} \mathrm{H} \mathrm{NMR}\left(500 \mathrm{MHz}, \mathrm{CDCl}_{3}\right)$ : $d=7.34-7.36(\mathrm{~m}, 2 \mathrm{H}), 7.27-7.31(\mathrm{~m}, 2 \mathrm{H}), 4.58(\mathrm{~s}, 2 \mathrm{H})$, $4.53(\mathrm{~m}, 4 \mathrm{H}), 4.34-4.39(\mathrm{~m}, 4 \mathrm{H}), 4.09(\mathrm{~m}, 2 \mathrm{H}), 3.54(\mathrm{~s}$, 2H), $3.42(\mathrm{~s}, 2 \mathrm{H}), 1.35(\mathrm{~s}, 3 \mathrm{H}), 1.11(\mathrm{~s}, 3 \mathrm{H}) ;{ }^{13} \mathrm{C}\left\{{ }^{1} \mathrm{H}\right\}$ $\mathrm{NMR}\left(126 \mathrm{MHz}, \mathrm{CDCl}_{3}\right): d=148.21,138.14,136.85$, $127.73,127.69,80.17,75.50,73.93,73.38,73.06$, 71.12, 39.90, 33.04, 21.42, 17.45; IR (neat): $1747 \mathrm{~cm}^{-1}$ $(\mathrm{C}=\mathrm{O})$; HRMS (ESI+): calcd. for $\mathrm{C}_{19} \mathrm{H}_{26} \mathrm{O}_{6}: \mathrm{m} / \mathrm{z}=$ $373.1626[\mathrm{M}+\mathrm{Na}]+$; found: 373.1625 .

\section{4-(hydroxymethyl)-1,3-dioxolan-2-one (16) ${ }^{[15 b]}$}

$\left[\mathrm{Al}^{\mathrm{tBu}}\right.$ ]: $2.5 \mathrm{~mol} \%$; [TBAB]: $5 \mathrm{~mol} \%$; T: $25 \% \mathrm{C}, p\left(\mathrm{CO}_{2}\right): 10$ bar, time: $18 \mathrm{~h}$; conversion: $99 \%$. Isolated by column chromatography (EtOAc:hexane $3: 1$ ) in $85 \%$ yield. ${ }^{1} \mathrm{H}$ NMR (500 MHz, [ $\left.\mathrm{D}_{6}\right]$ acetone): $d=4.88(\mathrm{~m}, 1 \mathrm{H}), 4.53-$ $4.61(\mathrm{~m}, 2 \mathrm{H}), 4.42(\mathrm{~m}, 1 \mathrm{H}), 3.88(\mathrm{~m}, 1 \mathrm{H}), 3.71(\mathrm{~m}, 1 \mathrm{H})$; ${ }^{13} \mathrm{C}\left\{{ }^{1} \mathrm{H}\right\}$ NMR (75 MHz, [D $\mathrm{D}_{6}$ acetone $): d=155.24,76.99$, 65.79, 61.21; IR (neat): $1763 \mathrm{~cm}^{-1}(\mathrm{C}=0)$.

\section{4-(2-hydroxyethyl)-1,3-dioxolan-2-one (17) ${ }^{[31]}$}

$\left[\mathrm{Al}^{\mathrm{tBu}}\right.$ ]: $2.5 \mathrm{~mol} \%$; [TBAB]: 5 mol\%; $\mathrm{T}: 60 \circ \mathrm{C}, p\left(\mathrm{CO}_{2}\right): 10$ bar, time: $18 \mathrm{~h}$; conversion: $99 \%$, selectivity $38 \%$. Isolated by column chromatography (EtOAc:hexane $1: 2$ to $1: 1 \mathrm{v} / \mathrm{v})$ in $33 \%$ yield. ${ }^{1} \mathrm{H}$ NMR $(400 \mathrm{MHz}$, $\left[\mathrm{D}_{6}\right.$ ] acetone $): d=4.95-4.99(\mathrm{~m}, 1 \mathrm{H}), 4.65(\mathrm{~m}, 1 \mathrm{H}), 4.26$ $(\mathrm{m}, 1 \mathrm{H}), 3.85(\mathrm{~m}, 1 \mathrm{H}), 3.71-3.77(\mathrm{~m}, 2 \mathrm{H}), 1.97-2.02(\mathrm{~m}$, 
$2 \mathrm{H}) ;{ }^{13} \mathrm{C}\left\{{ }^{1} \mathrm{H}\right\}$ NMR (126 MHz, [ $\left.\mathrm{D}_{6}\right]$ acetone $): d=154.73$, 75.12, 69.61, 57.20, 36.29; IR (neat): $1774 \mathrm{~cm}^{-1}(\mathrm{C}=0)$.

\section{4-(hydroxymethyl)oxazolidin-2-one (18) ${ }^{[32]}$}

[Al ${ }^{\mathrm{tBu}}$ ]: $2.5 \mathrm{~mol} \%$; [TBAB]: 5 mol\%; T: 25ㅇ, $p\left(\mathrm{CO}_{2}\right): 10$ bar, time: $18 \mathrm{~h}$; conversion: $99 \%$. Isolated by column chromatography using neutral alumina (EtOAc: $\mathrm{MeOH}$ 1:0 to $10: 1 \mathrm{v} / \mathrm{v})$ in $55 \%$ yield. ${ }^{1} \mathrm{H}$ NMR $(500 \mathrm{MHz}$, $\left[\mathrm{D}_{6}\right]$ acetone $): d=6.71(\mathrm{~s}, 1 \mathrm{H}), 4.42(\mathrm{t}, J=8.6 \mathrm{~Hz}, 1 \mathrm{H})$, $4.29(\mathrm{t}, J=5.5 \mathrm{~Hz}, 1 \mathrm{H}), 4.19(\mathrm{~m}, 1 \mathrm{H}), 3.89-3.99(\mathrm{~m}, 1 \mathrm{H})$, $3.60(\mathrm{~m}, 2 \mathrm{H}) ;{ }^{13} \mathrm{C}\left\{{ }^{1} \mathrm{H}\right\} \mathrm{NMR}$ (126 MHz, [ $\mathrm{D}_{6}$ ] acetone): $d=$ 159.23, 66.59, 63.33, 53.61; IR (neat): $1716 \mathrm{~cm}^{-1}$ $(\mathrm{C}=0)$.

\section{4-(hydroxymethyl)-3-methyloxazolidin-2-one (19)}

$\left[\mathrm{Al}^{\mathrm{tBu}}\right.$ ]: $2.5 \mathrm{~mol} \%$; [TBAB]: 5 mol\%; T: 25ㅇ, $p\left(\mathrm{CO}_{2}\right): 10$ bar, time: $18 \mathrm{~h}$; conversion: $99 \%$. Isolated by column chromatography using neutral alumina (EtOAc:Hexane 1:1 to $1: 0 \mathrm{v} / \mathrm{v})$ in $78 \%$ yield. ${ }^{1} \mathrm{H}$ NMR $(400 \mathrm{MHz}$, $\left[\mathrm{D}_{6}\right.$ ]acetone $): d=4.28-4.36(\mathrm{~m}, 1 \mathrm{H}), 4.13(\mathrm{~m}, 2 \mathrm{H})$, 3.78-3.86 (m, 2H), 3.59-3.68 (m, $1 \mathrm{H}), 2.83(\mathrm{~s}, 3 \mathrm{H})$; ${ }^{13} \mathrm{C}\left\{{ }^{1} \mathrm{H}\right\}$ NMR (126 MHz, [D $\mathrm{D}_{6}$ ]acetone): $d=158.20$, 99.99, 63.79, 60.15, 58.17; IR (neat): $1734 \mathrm{~cm}^{-1}(\mathrm{C}=0)$; HRMS (ESI+): calcd. for $\mathrm{C}_{5} \mathrm{H}_{9} \mathrm{NO}_{3}: \mathrm{m} / \mathrm{z}=154.0480$ $[\mathrm{M}+\mathrm{Na}]^{+}$; found: 154.0481 .

\section{5-(hydroxymethyl)-1,3-oxazinan-2-one $(20)^{[33]}$}

$\left[\mathrm{Al}^{\mathrm{tBu}}\right.$ ]: $2.5 \mathrm{~mol} \%$; [TBAB]: 5 mol\%; $\mathrm{T:} 45$ 으, $p\left(\mathrm{CO}_{2}\right): 10$ bar, time: $18 \mathrm{~h}$; conversion: $99 \%$. Isolated by washing the product with DCM followed by decantation of the liquid (the product is not soluble in DCM). The product was isolated in $84 \%$ yield. ${ }^{1} \mathrm{H} N M R(400 \mathrm{MHz}$, $\left[\mathrm{D}_{6}\right.$ ]acetone): $d=7.11(\mathrm{~s}, 1 \mathrm{H}), 4.79(\mathrm{t}, J=5.3 \mathrm{~Hz}, 1 \mathrm{H})$, $4.19(\mathrm{~m}, 1 \mathrm{H}), 3.99(\mathrm{~m}, 1 \mathrm{H}), 3.40(\mathrm{~m}, 2 \mathrm{H}), 3.20(\mathrm{~m}, 1 \mathrm{H})$, 2.91-3.03 $(\mathrm{m}, 1 \mathrm{H}), 1.95-2.08(\mathrm{~m}, 1 \mathrm{H}) ;{ }^{13} \mathrm{C}\left\{{ }^{1} \mathrm{H}\right\}$ NMR (126 MHz, [ $\left.\mathrm{D}_{6}\right]$ acetone): $d=153.25,68.06,59.57$, 41.40, 33.86; IR (neat): $1672 \mathrm{~cm}^{-1}$ (C=O); HRMS (ESI+): calcd. for $\mathrm{C}_{5} \mathrm{H}_{9} \mathrm{NO}_{3}: m / z=154.0480[\mathrm{M}+\mathrm{Na}]^{+}$; found: 154.0479.

\section{4-hydroxy-4-(thiazol-2-yl)-1,3-dioxolan-2-one (21)}

$\left[\mathrm{Al}^{\mathrm{tBu}}\right.$ ]: $2.5 \mathrm{~mol} \%$; [TBAB]: 5 mol\%; T: 50ㄷ, $p\left(\mathrm{CO}_{2}\right): 10$ bar, time: $18 \mathrm{~h}$; conversion: $95 \%$. Isolated by column chromatography (EtOAc:hexane 1:2 to $1: 1 \mathrm{v} / \mathrm{v}$ ) in $89 \%$ yield. ${ }^{1} \mathrm{H}$ NMR (500 MHz, [ $\left.\mathrm{D}_{6}\right]$ acetone): $d=7.91(\mathrm{~d}, J=$ $3.2 \mathrm{~Hz}, 1 \mathrm{H}), 7.79(\mathrm{~d}, J=3.2 \mathrm{~Hz}, 1 \mathrm{H}), 5.08-5.14(\mathrm{~m}, 1 \mathrm{H})$, $4.92(\mathrm{~s}, 2 \mathrm{H}), 4.03-4.15(\mathrm{~m}, 2 \mathrm{H}) ;{ }^{13} \mathrm{C}\left\{{ }^{1} \mathrm{H}\right\}$ NMR $(126 \mathrm{MHz}$, [ $\mathrm{D}_{6}$ ] acetone): $d=166.89,153.41,143.24,121.29$, 85.11, 70.40, 65.19; IR (neat): $1785 \mathrm{~cm}^{-1}$ (C=O); HRMS (ESI+): calcd. for $\mathrm{C}_{7} \mathrm{H}_{7} \mathrm{NO}_{4} \mathrm{~S}: \mathrm{m} / z=223.9993[\mathrm{M}+\mathrm{Na}]^{+}$; found: 223.9995.

\section{Crystallographic Studies}

The measured crystals were stable under atmospheric conditions; nevertheless they were treated under inert conditions immersed in perfluoro-polyether as protecting oil for manipulation. Data Collection: measurements were made on a Bruker-Nonius diffractometer equipped with an APPEX II 4K CCD area detector, a FR591 rotating anode with Mo K $\alpha$ radiation, Montel mirrors and a Kryoflex low temperature device $\left(\mathrm{T}=-173^{\circ} \mathrm{C}\right)$. Full-sphere data collection was used with $\omega$ and $\phi$ scans. Programs used: Data collection Apex2 V2011.3 (Bruker-Nonius 2008), data reduction Saint+Version 7.60A (Bruker AXS 2008) and absorption correction SADABS V. 2008-1 (2008). Structure Solution: SHELXTL Version 6.10 (Sheldrick, 2000) was used. ${ }^{[34]}$ Structure Refinement: SHELXTL-97-UNIX VERSION.

\section{Crystallographic Data for Compound 6.}

$\mathrm{C}_{17} \mathrm{H}_{24} \mathrm{O}_{4}, M_{\mathrm{r}}=292.36$, triclinic, $P-1, a=6.4725(3) \AA$ $=10.9994(5) \AA, c=45.127(2) \AA, a=83.0090(13)^{\circ}, b=$ 87.280(2) $)^{\circ}, g=85.6901(14)^{\circ}, V=3177.5(3) \AA^{3}, Z=8, \rho$ $=1.222 \mathrm{mg} \cdot \mathrm{M}^{-3}, m=0.086 \mathrm{~mm}^{-1}, I=0.71073 \AA$, $T=$ $100(2) \mathrm{K}, F(000)=1264$, crystal size $=0.04 \times 0.01 \times$ $0.002 \mathrm{~mm}, \theta(\min )=0.91^{\circ}, \theta(\max )=27.93^{\circ}, 57847$ reflections collected, 13322 reflections unique $\left(R_{\text {int }}=\right.$ $0.0512), \mathrm{GoF}=1.051, R_{1}=0.0530$ and $w R_{2}=0.1194$ [ $>2 \sigma(l)], R_{1}=0.1012$ and $w R_{2}=0.1399$ (all indices), $\mathrm{min} / \mathrm{max}$ residual density $=-0.386 / 0.330\left[\mathrm{e} \cdot \AA^{-3}\right]$. Completeness to $\vartheta\left(27.93^{\circ}\right)=87.1 \%$. 


\section{Crystallographic Data for Compound 9.}

$\mathrm{C}_{11} \mathrm{H}_{12} \mathrm{O}_{4}, M_{\mathrm{r}}=208.21$, monoclinic, $P 2(1), a=$ 10.9303(14) $\AA, b=17.646(3) \AA, c=11.1951(14) \AA, a=$ $g=90 \circ, b=114.658(4)^{\circ}, V=1962.3(5) \AA^{3}, Z=8, \rho=$ $1.409 \mathrm{mg} \cdot \mathrm{M}^{-3}, m=0.108 \mathrm{~mm}^{-1}, \mathrm{I}=0.71073 \AA, T=$ $100(2) \mathrm{K}, F(000)=880$, crystal size $=0.30 \times 0.15 \times 0.04$ $\mathrm{mm}, \theta(\min )=2.00^{\circ}, \theta(\max )=28.28^{\circ}, 8911$ reflections collected, 8911 reflections unique, $\mathrm{GoF}=1.040, R_{1}=$ 0.0633 and $w R_{2}=0.1642[I>2 \sigma(I)], R_{1}=0.0771$ and $\mathrm{w} R_{2}=0.1752$ (all indices), $\mathrm{min} / \mathrm{max}$ residual density $=$ $-0.438 / 0.311\left[\mathrm{e} \cdot \AA^{-3}\right]$. Completeness to $\vartheta\left(28.28^{\circ}\right)=$ $98.1 \%$. Flack parameter $x=0.2(7)$. The measured sample contained two single crystals domains and for its absorption correction the program TWINABS was used. ${ }^{[35]}$ The asymmetric unit is made up of four molecules of the compound.

\section{Crystallographic Data for Compound 11.}

$\mathrm{C}_{13} \mathrm{H}_{14} \mathrm{O}_{5}, M_{\mathrm{r}}=250.24$, monoclinic, $P 2(1) / \mathrm{c}, a=$ 15.8444(10) $\AA, b=5.8331$ (3) $\AA, c=13.8570$ (8) $\AA, a=g$ $=90 \circ, b=113.1386(17)^{\circ}, V=1177.67(12) \AA^{3}, Z=4, \rho=$ $1.411 \mathrm{mg} \cdot \mathrm{M}^{-3}, m=0.109 \mathrm{~mm}^{-1}, I=0.71073 \AA$ A,$T=$ $100(2) \mathrm{K}, F(000)=528$, crystal size $=0.60 \times 0.10 \times 0.10$ $\mathrm{mm}, \theta(\min )=2.80^{\circ}, \theta(\max )=30.62^{\circ}, 6893$ reflections collected, 6893 reflections unique, $\mathrm{GoF}=1.075, R_{1}=$ 0.0461 and $w R_{2}=0.1238[I>2 \sigma(I)], R_{1}=0.0534$ and $\mathrm{w} R_{2}=0.1288$ (all indices), $\mathrm{min} / \mathrm{max}$ residual density = $-0.271 / 0.366\left[\mathrm{e} \cdot \AA^{-3}\right]$. Completeness to $\vartheta\left(30.62^{\circ}\right)=$ $99.8 \%$.

\section{Crystallographic Data for Compound 15a.}

$\mathrm{C}_{20} \mathrm{H}_{26} \mathrm{O}_{8}, M_{\mathrm{r}}=394.41$, orthorhombic, $P \mathrm{bca}, a=$ $10.4970(8) \AA, b=11.6862(8) \AA, c=15.6413(12) \AA, a=$ $b=g=90 \circ, V=1918.7(2) \AA^{3}, Z=4, \rho=1.365 \mathrm{mg} \cdot \mathrm{M}^{-3}$, $m=0.106 \mathrm{~mm}^{-1}, I=0.71073 \AA, T=100(2) \mathrm{K}, F(000)=$ 840 , crystal size $=0.55 \times 0.04 \times 0.03 \mathrm{~mm}, \theta(\mathrm{min})=$ $2.60^{\circ}, \theta(\max )=25.63^{\circ}, 13409$ reflections collected, 1805 reflections unique $\left(R_{\text {int }}=0.0546\right), \mathrm{GoF}=1.045, R_{1}$ $=0.0420$ and $w R_{2}=0.1022[I>2 \sigma(I)], R_{1}=0.0703$ and $\mathrm{w} R_{2}=0.1148$ (all indices), $\mathrm{min} / \mathrm{max}$ residual density $=$
$-0.223 / 0.199\left[\mathrm{e} \cdot \AA^{-3}\right]$. Completeness to $\vartheta\left(25.63^{\circ}\right)=$ $99.7 \%$.

\section{Crystallographic Data for Compound 21.}

$\mathrm{C}_{7} \mathrm{H}_{7} \mathrm{NO}_{4} \mathrm{~S}, M_{\mathrm{r}}=201.20$, monoclinic, $P 2(1) / \mathrm{c}, a=$ 9.4979(14) $\AA, b=6.2542(10) \AA, c=14.097(2) \AA, a=g=$ 90ㅇ $, b=103.947(3)^{\circ}, V=812.7(2) \AA^{3}, Z=4, \rho=1.644$ $\mathrm{mg} \cdot \mathrm{M}^{-3}, m=0.377 \mathrm{~mm}^{-1}, I=0.71073 \AA, T=100(2) \mathrm{K}$, $F(000)=416$, crystal size $=0.40 \times 0.20 \times 0.04 \mathrm{~mm}$, $\theta(\min )=2.21^{\circ}, \theta(\max )=35.10^{\circ}, 16993$ reflections collected, 3443 reflections unique $\left(R_{\text {int }}=0.0365\right)$, GoF $=1.042, R_{1}=0.0298$ and $w R_{2}=0.0841[I>2 \sigma(l)], R_{1}=$ 0.0321 and $w R_{2}=0.0864$ (all indices), $\mathrm{min} / \mathrm{max}$ residual density $=-0.445 / 0.496\left[\mathrm{e} \cdot \AA^{-3}\right]$. Completeness to $\vartheta\left(35.10^{\circ}\right)=95.3 \%$.

\section{Acknowledgements}

W.G. thanks the CELLEX foundation for financial support and J.R. wishes to acknowledge the ICIQ for a predoctoral fellowship. ICIQ, ICREA and the Spanish Ministerio de Economía y Competitividad (MINECO) through Severo Ochoa Excellence Accreditation 20142018 (SEV-2013-0319) and project CTQ2014-60419-R are also acknowledged for their support.

Keywords: aluminium $\bullet$ carbon dioxide $\bullet$ cyclic carbonates $\bullet$ homogeneous catalysis $\bullet$ oxetanes

[1] For recent reviews: a) M. Aresta, A. Dibenedetto, A. Angelini, Chem. Rev. 2014, 114, 17091742; b) N. Kielland, C. J. Whiteoak, A. W. Kleij, Adv. Synth. Catal. 2013, 355, 2115-2138; c) B. Yu, L.-N. He, ChemSusChem 2015, 8, 52-62; d) M. Cokoja, C. Bruckmeier, B. Rieger, W. A. Herrmann, F. E. Kühn, Angew. Chem. Int. Ed. 2011, 50, 8510-8537; e) H. Maeda, Y. Miyazaki, T. Ema, Catal. Sci. Technol. 2014, 4, 1482-1497; f) M. Peters, B. Köhler, W.

Kuckshinrichs, W. Leitner, P. Markewitz, T. E. Müller, ChemSusChem 2011, 4, 1216-1240; g) Q. Liu, L. Wu, R. Jackstell, M. Beller, Nat. Commun. 2015, 6, 5933. 
[2] a) S. Perathoner, G. Centi, ChemSusChem 2014, 7, 1274-1282; b) E. A. Quadrelli, G. Centi, J.-L. Duplan, S. Perathoner, ChemSusChem 2011, 4, 11941215.

[3] See for instance: a) O. Jacquet, $X$. Frogneux, $C$. Das Neves Gomes, T. Cantat, Chem. Sci. 2013, 4, $2127-$ 2131; b) I. I. F. Boogaerts, S. P. Nolan, J. Am. Chem. Soc. 2010, 132, 8858-8859; c) M. Khandelwal, R. J. Wehmschulte, Angew. Chem. Int. Ed. 2012, 51, 73237326.

[4] a) C. Martin, G. Fiorani, A. W. Kleij, ACS Catal. 2015, 5, 1353-1370; b) J. W. Comerford, I. D. V. Ingram, M. North, X. Wu, Green Chem. 2015, 17, 1966-1987; c) A. Decortes, A. M. Castilla, A. W. Kleij, Angew. Chem. Int. Ed. 2010, 49, 9822-9837; d) P. P. Pescarmona, M. Taherimehr, Catal. Sci. Technol. 2012, 2, 2169-2187.

[5] a) X.-B. Lu, D. J. Darensbourg, Chem. Soc. Rev. 2012, 41, 1462-1484; b) D. J. Darensbourg, Chem. Rev. 2007, 107, 2388-2410; c) G. W. Coates, D. R. Moore, Angew. Chem. Int. Ed. 2004, 43, 6618-6639; d) M. R. Kember, A. Buchard, C. K. Williams, Chem. Commun. 2011, 47, 141-163; e) K. Nozaki, Pure Appl. Chem. 2004, 76, 541-546; f) X.-B. Lu, W.-M. Ren, G.-P. Wu, Acc. Chem. Res. 2012, 45, 1721-1735.

[6] a) T. Sakakura, K. Kohno, Chem. Commun. 2009, 1312-1330; b) B. Schäffner, F. Schäffner, S. P. Verevkin, A. Börner, Chem. Rev. 2010, 110, 45544581; c) J. H. Clements, Ind. Eng. Chem. Res. 2003, 42, 663-674.

[7] a) G. Fiorani, W. Guo, A. W. Kleij, Green Chem. 2015, 17, 1375-1389; b) A. Tlili, E. Blondiaux, X. Frogneux, T. Cantat, Green Chem. 2015, 17, 157-168.

[8] For some recent examples: a) D. Tian, B. Liu, Q. Gan, H. Li, D. J. Darensbourg, ACS Catal. 2012, 2, 2029-2035; b) W. Clegg, R. Harrington, M. North, R. Pasquale, Chem. Eur. J. 2010, 16, 6828-6843; c) A. Monassier, V. D'Elia, M. Cokoja, J. Pelletier, J.-M.
Basset, F. E. Kühn, ChemCatChem 2013, 5, 1321-1324; d) A. Decortes, A. W. Kleij, ChemCatChem 2011, 3, 831-834.

[9] a) B. R. Buckley, A. P. Patel, K. G. Upul Wijayantha, Eur. J. Org. Chem. 2015, 474-478; b) D. J. Darensbourg, A. Horn Jr, A. I. Moncada, Green Chem. 2010, 12, 1376-1379; c) C. J. Whiteoak, E. Martin, M. M. Belmonte, J. Benet-Buchholz, A. W. Kleij, Adv. Synth. Catal. 2012, 354, 469-476. Please note that other methods towards 6MCCs have been reported but these methods often suffer from the use of toxic reagents such as phosgene/chloroformates, produce stoichiometric amounts of halide waste or require harsh reaction conditions. See for some example: d) T. Ariga, T. Takata, T. Endo, Macromolecules 1997, 30, 737-744; e) A. N. Zelikin, P. N. Zawaneh, D. Putnam, Biomacromolecules 2006, 7, 3239-3244; f) W. C. Ray III, M. W. Grinstaff, Macromolecules 2003, 36, 35573562; g) G. Rokicky, T. Kowalczyk, M. Glinksi, Polym. J. 2000, 32, 381-390; h) M. R. Reithofer, Y. Ngai Suma, Y. Zhang, Green Chem. 2013, 15, 2086-2090. Note that also the use of dialkylcarbonates with respect to $6 \mathrm{MCC}$ formation has been reported; the industrial preparation of dialkylcarbonates typically requires toxic reagents such as phosgene and/or harsh reaction conditions. For a recent review: i) N. Keller, G. Rebmann, V. Keller, J. Mol. Cat. A: Chem. 2010, 317, 1-18.

[10] a) D. J. Darensbourg, W. Choi, O. Karroonnirun, N. Bhuvanesh, Macromolecules 2008, 41, 3493-3502; b) D. J. Darensbourg, A. I. Moncada, W. Choi, J. H. J. Reibenspies, J. Am. Chem. Soc. 2008, 130, 6523-6533; c) D. J. Darensbourg, A. I. Moncada, Macromolecules 2010, 43, 5996-6003. See also: d) J. Mindemark, J. Hilborn, T. Bowden, Macromolecules 2007, 40, 3515-3517.

[11] D. J. Darensbourg, A. I. Moncada, S.-H. Wei, Macromolecules 2011, 44, 2568-2576. 
[12] a) M. Helou, O. Miserque, J.-M. Brusson, J.-F. Carpentier, S. M. Guillaume, Chem. Eur. J. 2010, 16, 13805-13813; b) S. M. Guillaume, J.-F. Carpentier, Catal. Sci. Technol. 2012, 2, 898-906. For a seminal contribution to this topic: c) S. J. Inoue, Polym. Sci. Part A. 2000, 38, 2861-2871.

[13] a) A. P. Pêgo, M. J. A. van Luyn, L. A. Brouwer, P. B. van Wachem, A. A. Poot, D. W. Grijpma, J. J. Feijen, Biomed. Mater. Res. 2003, 67A, 1044-1054.

[14] a) J. Mindemark, T. Bowden, Polymer 2011, 52, 5716-5722; b) J. Mindemark, T. Bowden, Polym. Chem. 2012, 3, 1399-1401.

[15] a) V. Laserna, G. Fiorani, C. J. Whiteoak, E. Martin, E. C. Escudero-Adán, A. W. Kleij, Angew. Chem. Int. Ed. 2014, 53, 10416-10419; b) C. J. Whiteoak, N. Kielland, V. Laserna, E. C. EscuderoAdán, E. Martin, A. W. Kleij, J. Am. Chem. Soc. 2013, 135, 1228-1231; c) C. J. Whiteoak, N. Kielland, V. Laserna, F. Castro-Gómez, E. Martin, E. C. EscuderoAdán, C. Bo, A. W. Kleij, Chem. Eur. J. 2014, 20, 22642275; d) C. J. Whiteoak, E. Martin, E. C. EscuderoAdán, A. W. Kleij, Adv. Synth. Catal. 2013, 355, 22332239.

[16] K. M. Tomczyk, P. A. Guńka, P. G. Parzuchowski, J. Zachara, G. Rokicki, Green Chem.

2012, 14, 1749-1758. Please also note that column purification of the crude $6 \mathrm{MCC}$ in some cases resulted in significant 1,3-diol formation (noted for instance in the purification of 2) thereby compromising the isolated yield. Therefore it is recommended to carry out the column separation of the $6 \mathrm{MCC}$ without too much delay.

[17] CCDC numbers $1056843-1056847$ contain the supplementary X-ray data.

[18] S. Minakata, I. Sasaki, T. Ide, Angew. Chem. Int. Ed. 2010, 49, 1309-1311.
[19] Y. Takeda, S. Okumura, S. Tone, I. Sasaki, S. Minakata, Org. Lett. 2012, 14, 4874-4877.

[20] R. N. Loy, E. N. Jacobsen, J. Am. Chem. Soc. 2009, 131, 2786-2787.

[21] For non-innocent behavior of Al-complexes refer to: L. A. Berben, Chem. Eur. J. 2015, 21, 27342742.

[22] The use of this substrate gave 3-hydroxytrihydrofuran as a major product; see the Supporting Information for more details.

[23] M. Kol, M. Shamis, I. Goldberg, Z. Goldschmidt, S. Alfi, E. Hayut-Salant, Inorg. Chem. Commun. 2001, 4, 177-179.

[24] K. Okuma, Y. Tanaka, S. Kaji, H. Ohta, J. Org. Chem. 1983, 48, 5133-5134.

[25] M. A. Blaskovich, G. Evindar, N. G. W. Rose, S. Wilkinson, Y. Luo, G. A. Lajoie, J. Org. Chem. 1998, 63, 3631-3646.

[26] P. Picard, D. Leclercq, J. P. Bats, J. Moulines, Synthesis 1981, 550-551.

[27] N. Merkley, J. Warkentin, Can. J. Chem. 2002, 80, 1187-1195.

[28] W. Guerin, M. Helou, M. Slawinski, J.-M. Brusson, J.-F. Carpentier, S. M. Guillaume, Polym. Chem. 2014, 5, 1229-1240.

[29] J. Mindemark, T. Bowden, Polymer 2011, 52, 5716-5722.

[30] N. Nemoto, F. Sanda, T. Endo, J. Polym. Sci. Part A: Polym. Chem. 2001, 39, 1305-1317.

[31] D. M. Pearson, N. R. Conley, R. M. Waymouth, Adv. Synth. Catal. 2011, 353, 3007-3013. 
[32] T. J. Donohoe, M. J. Chughtai, D. J. Klauber, D. Griffin, A. D. Campbell, J. Am. Chem. Soc. 2006, 128, 2514-2515.

[33] G. Bourgery, B. Bucher, P. Guerret, G. Mocquet, G. Moinet, DELALANDE SA 1984, 1-30.
[34] G. M. Sheldrick, SHELXTL Crystallographic System, version 6.10; Bruker AXS, Inc.: Madison, WI, 2000.

[35] TWINABS Version 2008/4 Bruker AXS, see: R. H. Blessing, Acta Cryst. 1995, A51, 33-38. 


\section{Entry for the Table of Contents:}

\section{FULL PAPER}

\section{A highly selective and}

general catalytic method

for the coupling between

oxetanes and $\mathrm{CO}_{2}$ is reported. The methodology combines cheap and nontoxic catalyst components, functional group tolerance and wide scope in reaction partners under mild conditions. The first examples of ambient oxetane $/ \mathrm{CO}_{2}$ coupling reactions are reported, and the resultant heterocyclic
Jeroen Rintjema, Wusheng Guo, Eddy Martin, Eduardo C. Escudero-Adán, Arjan W. Kleij*

Page No. - Page No.

\section{Highly Chemo-Selective}

Catalytic Coupling of

Substituted Oxetanes and Carbon Dioxide 